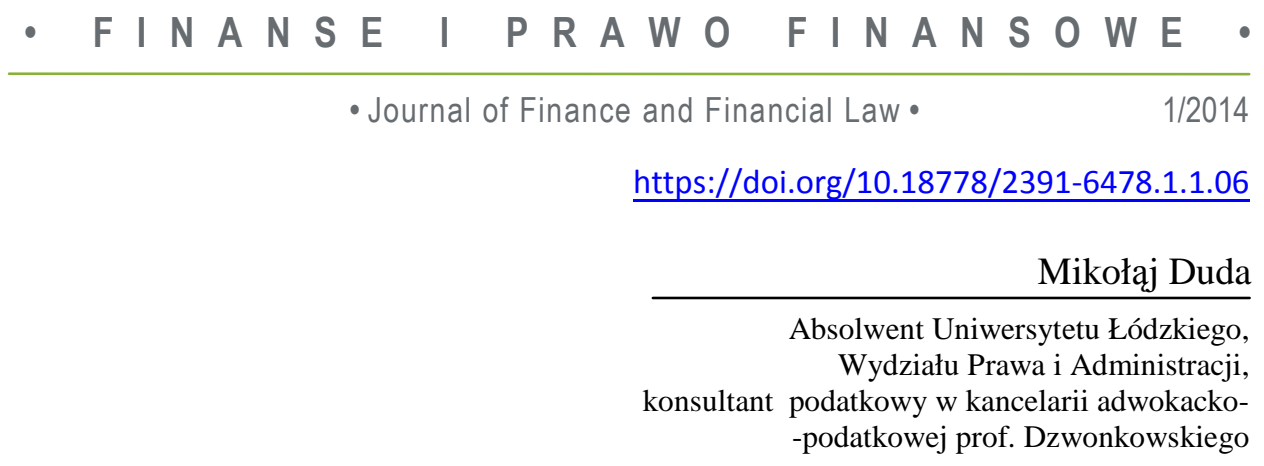

\title{
DLUG PUBLICZNY I PRAKTYCZNE PROBLEMY REALIZACJI PROCEDUR OSTROŻNOŚCIOWYCH
}

\begin{abstract}
Streszczenie
Celem artykułu jest przybliżenie aktualnych problemów związanych z interpretacją pojęcia długu publicznego na gruncie ustawy o finansach publicznych, jego zgodności z Konstytucją oraz wskazanie wątpliwości wiążących się z ewentualnym zastosowaniem procedur ostrożnościowych dotyczących długu publicznego. Zdaniem autora niektóre przepisy wymagają pilnej interwencji ustawodawcy, zwłaszcza biorąc pod uwagę, że część procedur ostrożnościowych może zwyczajnie nie dać się wcielić w życie.
\end{abstract}

Słowa kluczowe: finanse publiczne, dług publiczny, deficyt budżetowy, progi ostrożnościowe.

\section{WPROWADZENIE}

Państwowy dług publiczny jest obecnie dominującym tematem w dyskursie publicznym na temat stanu finansów państwa. Przy czym wciąż nie ma wystarczająco dużo opracowań dotyczących ustalenia faktycznego zakresu pojęcia długu publicznego, jak i wyczerpującego opisania instytucji procedur ostrożnościowych i sanacyjnych, zawartych w Konstytucji oraz w ustawie o finansach publicznych. Dlatego celem przyświecającym autorowi jest poruszenie problemów związanych z interpretacją definicji długu publicznego oraz hipotetycznych rezultatów zastosowania progów ostrożnościowych. Przedmiotem badania jest Konstytucja Rzeczypospolitej Polskiej z 2 dnia kwietnia 1997 r. oraz Ustawa $z$ dnia 27 sierpnia 2009 r. o finansach publicznych z uwzględnieniem zmian z 26 lipca 2013 r. dotyczących zawieszenia progów ostrożnościowych, a także założenia nowej reguły wydatkowej. 


\section{POJECIE DŁUGU PUBLICZNEGO}

Dług publiczny najczęściej definiuje się jako całość zobowiązań władz publicznych z tytułu zaciągniętych pożyczek. Najważniejszą przyczyną powstawania długu publicznego są deficyty budżetowe. Zobowiązania władz publicznych mogą również wynikać z tytułu kredytów i pożyczek udzielonych ze środków publicznych, odszkodowań wobec podmiotów i obywateli, przyjętych depozytów i wymagalnych zobowiązań jednostek budżetowych [Ziółkowska 2012: 284].

Najważniejszy przepis w naszej hierarchii prawa poruszający problem długu publicznego znajduje się w art. 216 ust. 5 Konstytucji RP z dnia 2 kwietnia $1997 r$. Przepis ten ustala konstytucyjny limit długu publicznego - zgodnie z nim, nie wolno zaciągać pożyczek lub udzielać gwarancji i poręczeń finansowych, w następstwie których państwowy dług publiczny przekroczy 3/5 wartości rocznego produktu krajowego brutto. Konstytucja nakłada dodatkowo obowiązek skierowany wobec ustawodawcy, polegający na tym, że zarówno sposób obliczania wartości rocznego produktu krajowego brutto oraz państwowego długu publicznego musi określać ustawa. Delegacja ta jest zrealizowana w przepisach Ustawy o finansach publicznych z dnia 27 czerwca 2005 r. Należy przy tym zauważyć, że ustawa o finansach publicznych oprócz pojęcia długu publicznego rozróżnia także pojęcie długu Skarbu Państwa - nie jest ono jednak zdefiniowane. Biorąc pod uwagę całość obowiązujących przepisów można jednak przyjąć, że pod pojęciem tym kryje się nominalna wartość zobowiązań tego podmiotu. Skarb Państwa, mimo że nie został wymieniony w katalogu jednostek sektora finansów publicznych zawartym w art. 9 u.f.p., jest uznawany za składowy element tego sektora [Ruśkowski i Salachna 2010: 78]. Wnioskując z powyższego, dług Skarbu Państwa jest częścią większej całości, jaką jest państwowy dług publiczny.

Definicja ustawowa długu publicznego została zawarta w art. 72 ust. 1 ustawy o finansach publicznych. Zgodnie z nim, państwowy dług publiczny obejmuje zobowiązania sektora finansów publicznych z następujących tytułów: wyemitowanych papierów wartościowych opiewających na wierzytelności pieniężne, zaciągniętych kredytów i pożyczek, przyjętych depozytów oraz wymagalnych zobowiązań. W kolejnym ustępie przepisu znajduje się delegacja, nakazująca Ministrowi Finansów określenie, w drodze rozporządzenia, szczegółowego sposobu klasyfikacji tytułów dłużnych zaliczanych do państwowego długu publicznego, w tym rodzajów zobowiązań zaliczanych do tytułów dłużnych, uwzględniając podstawowe kategorie przedmiotowe i podmiotowe zadłużenia oraz okresy zapadalności. Należy przy tym zaznaczyć, że obecne brzmienie przepisu zostało ustalone nowelizacją ustawy o finansach publicznych, która weszła w życie 1.01.2011 r. Nowelizacja polegała na dodaniu do treści przepisu wyrażenia „w tym rodzaje zobowiązań zaliczanych do tytułów dłużnych” 
[Bitner i Kulesza 2011: 15]. Minister Finansów zrealizował nową delegację wydając Rozporzadzenie z dnia 23 grudnia 2010r. w sprawie szczegótowego sposobu klasyfikacji tytułów dtużnych zaliczanych do państwowego dtugu publicznego, w tym do długu Skarbu Państwa. Następnie zostało ono zastąpione przez Rozporzqdzenie z dnia 28 grudnia 2011r. w sprawie szczegótowego sposobu klasyfikacji tytutów dtużnych zaliczanych do państwowego dtugu publicznego.

Przedstawiona nowelizacja znalazła się pod uzasadnioną krytyką przedstawicieli doktryny. Według autorów, ustawowe upoważnienie do wydania rozporządzenia w nowym brzmieniu narusza zasady wydawania rozporządzeń określone w art. 92 ust. 1 Konstytucji, orzecznictwie TK oraz doktrynie prawa. W związku z tym, zarzucają oni art. 72 ust. 1 ustawy o finansach publicznych w nowym brzmieniu - sprzeczność z konstytucją. Aby odnieść się do zarzutów, należy najpierw nadmienić, że Konstytucja określa zasady techniki legislacyjnej, odnoszące się do rozporządzeń. Zgodnie z nią, rozporządzenie jest aktem wydawanym na podstawie szczegółowego upoważnienia zawartego w ustawie i w celu jej wykonania. Upoważnienie to powinno określać organ właściwy do wydania rozporządzenia i zakres spraw przekazanych do uregulowania oraz wytyczne dotyczące treści aktu. Rozporządzenie jest więc aktem wykonawczym, które ma tylko doprecyzowywać treści zawarte w ustawie. Niezastosowanie się do tej zasady może powodować powstawanie rozporządzeń ogólnikowych, wręcz blankietowych. Nadmierna ogólnikowość upoważnienia była wielokrotnie krytykowana, powoduje bowiem, że zakres przedmiotowy upoważnienia jest trudny do precyzyjnego ustalenia i daje możliwość przesuwania materii ustawowej do rozporządzeń, w tym w szczególności formułowania w akcie wykonawczym dodatkowych obowiązków. Nie można wykonywać w drodze rozporządzenia tego, co nie zostało uregulowane w ustawie [Bitner i Kulesza 2011: 28]. Delegacja zawarta $w$ poprzednim brzmieniu przepisu art. 72 ust. 2 u.f.p. z 2005 r. była zgodna z powyższymi wymaganiami stawianymi upoważnieniom do wydania aktów wykonawczych. Zgodnie z poprzednią regulacją, rozporządzenie miało jedynie szczegółowo sklasyfikować tytuły dłużne zaliczane do państwowego długu publicznego. Ustawa nowelizująca dokonała jednak zmiany upoważnienia ustawowego. Aktualne brzmienie delegacji jest trudne do zaakceptowania z racji braku wystarczającej określoności. Wyrażenie „sposób klasyfikacji tytułów dłużnych zaliczanych do państwowego długu publicznego, w tym rodzaje zobowiązań zaliczanych do tytułów dłużnych" jest nieprecyzyjne i czyni takie upoważnienie ustawowe w istocie blankietowym [Bitner i Kulesza 2011: 29]. Występuje problem określenia pojęć „,klasyfikacji tytułów dłużnych” i „rodzajów zobowiązań zaliczanych do tytułów dłużnych”. Wydaje się, że to drugie pojęcie jest nadrzędne wobec pierwszego. Przyjmując tę interpretację, możemy powiedzieć, że ustawa o finansach publicznych $w$ art. 72 ust. 2 przekazała do uregulowania w rozporządzeniu określenie rodzajów zobowiązań zaliczanych do tych 
tytułów - sugerując tym samym, że ich wymienienie w ust. 1 nie ma charakteru zamkniętego.

W związku z tym art. 72 ust. 2 ustawy o finansach publicznych wydaje się być niezgodnym z art. 216 ust. 5 Konstytucji, w którym stwierdzono, że sposób obliczenia wartości państwowego długu publicznego określa ustawa. Mamy bowiem do czynienia $\mathrm{z}$ delegacją uprawniającą do wydania rozporządzenia, które może zawierać inne rodzaje zobowiązań zaliczanych do tytułów dłużnych, niż wskazane w ustawie o finansach publicznych. Oznacza to, że ustawodawca założył otwarty charakter tytułów dłużnych zaliczanych do państwowego długu publicznego, który może być doprecyzowany przez rozporządzenie. Jest to sprzeczne z Konstytucją, która założyła, że sposób obliczania długu publicznego jest uregulowany w ustawie.

\section{METODOLOGIE LICZENIA WYSOKOŚCI DLUGU PUBLICZNEGO}

Zgodnie z art. 73 ustawy o finansach publicznych państwowy dług publiczny oblicza się jako wartość nominalną zobowiązań jednostek sektora finansów publicznych po wyeliminowaniu wzajemnych zobowiązań między jednostkami tego sektora. Wyeliminowanie wzajemnych zobowiązań między jednostkami sektora finansów publicznych oznacza, że nie zalicza się do niego m. in. udzielanych z budżetu państwa pożyczek dla jednostek samorządu terytorialnego w ramach postępowań ostrożnościowych lub naprawczych, a także pożyczek udzielanych samodzielnym zakładom opieki zdrowotnej [Karlikowska 2010: 205]. Następnie ustawodawca w art. 73 ust. 2 ustawy próbuje zdefiniować pojęcie „wartości nominalnej”, ale jest to definicja niedoskonała (typu idem per idem), ponieważ definiowane pojęcie określono identycznym zwrotem (,,przez wartość nominalną zobowiązania rozumie się wartość nominalną"). Zgodnie z tym przepisem, przez wartość nominalną zobowiązania rozumie się jego wartość nominalną:

a) wyemitowanych papierów wartościowych,

b) zaciągniętej pożyczki, kredytu lub innego zobowiązania, to jest kwotę świadczenia głównego, należną do zapłaty w dniu wymagalności zobowiązania.

Szczegółowy sposób ustalania wartości zobowiązań zaliczanych do państwowego długu publicznego jest zawarty Rozporządzeniu Ministra Finansów $z$ dnia 30 marca 2010 r. w sprawie szczegótowego sposobu ustalania wartości zobowiazań zaliczanych do państwowego dtugu publicznego, dtugu Skarbu Państwa, wartości zobowiazań z tytułu poręczen i gwarancji.

Ramy sektora finansów publicznych zostały określone w art. 8 ustawy o finansach publicznych. Należy zwrócić uwagę na to, że poza zakresem sektora 
znajduje się Krajowy Fundusz Drogowy i Fundusz Kolejowy, co ma duży wpływ na ostatecznie wyliczoną wysokość długu publicznego.

W prawie Unii Europejskiej definicję długu publicznego z wyszczególnieniem tytułów dłużnych zawarto w Rozporzadzeniu Rady nr 479/2009 o stosowaniu Protokołu w sprawie procedury dotyczacej nadmiernego deficytu zataczonego do Traktatu ustanawiającego Wspólnotę Europejska (obecnie TFUE). Zgodnie $\mathrm{z}$ art. 1 ust. 1 tego rozporządzenia, dług publiczny oznacza całościowy dług brutto według wartości nominalnej pozostałej pod koniec roku w sektorze administracji publicznej, z wyłączeniem tych pasywów, które odpowiadają aktywom finansowym, jakimi dysponuje sektor administracji publicznej [por. Bitner i Kulesza 2011: 16]. Co więcej, na dług składają się pasywa w trzech kategoriach:

a) gotówka i depozyty,

b) papiery wartościowe inne niż akcje, wyłączając pochodne instrumenty finansowe,

c) pożyczki.

Natomiast sektor finansów publicznych w prawie unijnym jest równoznaczny z pojęciem „sektor władz rządowych i samorządowych” zdefiniowanym w systemie rachunków ESA 95. Obejmuje on następujące jednostki instytucjonalne:

- jednostki rządowe i samorządowe, które administrują i finansują grupę działalności polegających głównie na dostarczaniu towarów i usług nierynkowych, przeznaczonych na zaspokojenie potrzeb społeczeństwa,

- instytucje nie nastawione na przynoszenie dochodu uznane za podmioty prawne będące kontrolowane i głównie finansowane przez jednostki rządowe i samorządowe,

- autonomiczne fundusze emerytalne.

Wnioskując z wysokości długu publicznego liczonego obydwiema przedstawionymi wyżej metodami można stwierdzić, że obrazują znacznie różny stan polskich finansów publicznych. Wynika to głównie ze sposobu zaliczenia Krajowego Funduszu Drogowego, którego dług w roku 2009 r. szacowano na 14 817,1 mln zł [Ziółkowska 2012: 289]. Wyłączenie zadłużenia KFD z pojęcia długu publicznego według metodologii polskiej statystycznie znacznie obniża jego wysokość. Wydaje się to jednak jedynie metodą księgową która zabezpiecza przed ryzykiem przekroczenia ustawowego progu zadłużenia określonego na poziomie $55 \%$ wartości krajowego produktu brutto. Nie znajduję żadnych naukowych uzasadnień wyłączenia tej jednostki z sektora finansów publicznych. Jest ona w całości zależna od wpłat pieniężnych od innych jednostek sektora rządowego. Dla porównania, jednym z kryteriów zaliczenia jednostki do sektora rządowego i samorządowego według metodologii ESA 95 jest właśnie finansowanie głównie z obowiązkowych płatności dokonywanych przez jednostki należące do pozostałych sektorów. 
66 Mikołaj Duda, Dług publiczny i praktyczne problemy realizacji...

Tabela 1. Dług publiczny liczony według regulacji polskiej i unijnej w mln zł

\begin{tabular}{|l|c|}
\hline \multicolumn{1}{|c|}{ Wyszczególnienie } & Kwota \\
\hline Państwowy dług publiczny & 669881,4 \\
\hline Dług według Traktatu z Maastricht & 684266,1 \\
\hline
\end{tabular}

Źródło: Ziółkowska [2012: 289].

\section{LIMIT DŁUGU PUBLICZNEGO W POLSCE I PROGI OSTROŻNOŚCIOWE}

Konstytucja Rzeczypospolitej $z$ dnia 2 kwietnia 1997 r. w art. 216 ust. 5 wprowadziła prawny limit długu publicznego - zgodnie z tym przepisem, górny próg wysokości długu publicznego wynosi $60 \%$ wartości rocznego produktu krajowego brutto. Jest to jedyny w Europie przypadek nałożenia limitu wysokości długu publicznego w akcie prawnym tej rangi. Poziom długu publicznego jest także istotny z perspektywy Traktatu o funkcjonowaniu Unii Europejskiej, gdzie $\mathrm{z}$ art. 104 ust. 1 wynika, że stosunek pomiędzy wysokością długu publicznego a PKB jest brany pod uwagę przy ocenie, czy zastosowana zostanie procedura nadmiernego deficytu. $\mathrm{Z}$ kolei protokół do stosowania procedury w przypadku nadmiernego deficytu określa bazowy stosunek długu do PKB na poziomie 60\%. Konstytucja z $1997 \mathrm{r}$. więc w pełni realizuje unijne zabezpieczenia związane z wysokością długu publicznego. Próg długu określony w art. 216 ust. 5 Konstytucji jest o tyle istotny, że w przypadku jego przekroczenia niemożliwe jest zaciąganie jakichkolwiek pożyczek ani udzielanie gwarancji i poręczeń finansowych. Całkowicie uniemożliwia więc dalsze zapożyczanie się sektora finansów publicznych na obsługę długu publicznego i jako jedyne wyjście z sytuacji wymusza dokonanie znaczących cięć w wydatkach budżetowych, w wyniku których saldo budżetu będzie co najmniej w równowadze (nie wystąpi deficyt).

Ustawa o finansach publicznych wprowadza także kolejne, niewynikające z Konstytucji progi ostrożnościowe, ustanowione na poziomie odpowiednio 50\% i 55\% produktu krajowego brutto. Przekroczenie przez dług publiczny tych progów, jak i zakazu określonego w art. 216 ust. 5 Konstytucji, powoduje powstanie szeregu obowiązków ciążących na organach państwowych. Zgodnie z art. 47 ust. 3 Minister Finansów także sprawdza realizację owych obowiązków. $\mathrm{W}$ związku z tą kontrolą, ma prawo żądania od jednostek sektora finansów publicznych dodatkowych informacji o bieżącym i prognozowanym zadłużeniu tych jednostek oraz o strukturze zadłużenia. W przypadku wykrycia nieprawidłowości, informuje o nich odpowiednie organy nadzoru. 
Pierwszy próg ostrożnościowy jest przekroczony, gdy wartość relacji państwowego długu publicznego do PKB jest większa od 50\%, ale nie większa niż $55 \%$. W takim przypadku ustawa nakazuje, aby na kolejny rok Rada Ministrów uchwaliła projekt ustawy budżetowej, w którym relacja deficytu do dochodów budżetu państwa nie była wyższa niż analogiczna relacja z roku bieżącego wynikająca $\mathrm{z}$ ustawy budżetowej. Konsekwencje przekroczenia tego progu nie są dotkliwe. Zakłada on, że wydatki w stosunku do dochodów muszą pozostać na tym samym poziomie. W praktyce oznacza to jednak, że przy wzroście gospodarczym, który generuje coraz wyższe dochody, wydatki budżetowe i tak mogą rosnąć mimo niezmienionej relacji dochodów do wydatków budżetu. Potwierdzają to wciąż wzrastające nominalne kwoty wydatków budżetowych od roku 2010, w którym po raz pierwszy relacja długu publicznego do PKB osiągnęła 50\%.

W chwili obecnej pierwszy próg ostrożnościowy został zawieszony na podstawie Ustawy $z$ dnia 26 lipca 2013 r. o zmianie ustawy o finansach publicznych. Zgodnie z brzmieniem tego aktu, w ustawie o finansach publicznych wprowadza się art. 86a w brzmieniu ,przepisu art. 86 ust. 1 pkt 1 nie stosuje się w roku 2013”. Konieczność zawieszenia pierwszego progu ostrożnościowego była spowodowana koniecznością nowelizacji ustawy budżetowej na rok 2013. Rząd w obliczu znacznego spadku dochodów budżetowych w ciągu roku stanął przed dylematem: czy przeprowadzić znaczne cięcia w wydatkowaniu publicznym, czy dokonać mniejszej redukcji wydatków wraz z zapisaniem w ustawie budżetowej wyższej niż zakładanej na rok 2013 kwoty deficytu budżetowego. Na przeszkodzie drugiego rozwiązania stanął pierwszy próg ostrożnościowy ustawa budżetowa na rok 2013 została uchwalona już z pełnym wykorzystaniem zasady, iż relacja deficytu do dochodów budżetu państwa nie może być wyższa niż analogiczna relacja z roku 2012. Rząd zdecydował się więc na zawieszenie progu ostrożnościowego. Na marginesie należy dodać, że zawieszanie mechanizmów zabezpieczających stan finansów publicznych w miarę potrzeby przekreśla sam sens ich ustanawiania. W odpowiednim czasie należało albo uchwalić budżet na rok 2013 przyjmując mniej optymistyczne założenia makroekonomiczne albo przeprowadzić reformę wydatkowania publicznego.

Jeżeli relacja długu publicznego do PKB jest większa od 55\%, a mniejsza od $60 \%$, osiągnięty jest drugi próg ostrożnościowy. Jego skutki są dalece bardziej dotkliwe, zarówno dla budżetu jak i politycznie dla partii rządzącej, a do najważniejszych trzeba zaliczyć to, że:

- Na kolejny rok Rada Ministrów uchwala projekt ustawy budżetowej, w którym w ogóle nie przewiduje się deficytu budżetu państwa albo przyjmuje się takie saldo dochodów i wydatków, które zapewni, że relacja długu do PKB spadnie. Dodatkowo:

a. Nie przewiduje się wzrostu wynagrodzeń pracowników sfery budżetowej,

b. Waloryzacja rent i emerytur nie może przekroczyć poziomu inflacji,

c. Wprowadza się zakaz udzielania pożyczek i kredytów z budżetu państwa z wyjątkiem rat kredytów i pożyczek udzielonych w latach poprzednich. 
- Rada Ministrów przedstawia Sejmowi program sanacyjny mająca na celu obniżenie relacji długu do PKB;

- Rada Ministrów dokonuje przeglądu obowiązującej regulacji prawnej w celu przedstawienia rozwiązań mających wpływ na wzrost dochodów budżetu państwa, w tym dotyczące stawek podatku od towarów i usług.

Trzeci próg ostrożnościowy zawarty w art. 87 ust. 1 lit. c pokrywa się z dyspozycją art. 216 ust. 5 Konstytucji i dotyczy przekroczenia długu publicznego granicy $60 \%$ w stosunku do PKB. Głównym skutkiem jest zobowiązanie Rady Ministrów do przedstawienia Sejmowi programu sanacyjnego mającego na celu ograniczenie tej relacji do poziomu poniżej $60 \%$.

Program sanacyjny jest dokumentem, który powinien obejmować wskazanie przyczyn kształtowania się relacji państwowego długu publicznego do PKB, program przedsięwzięć mających na celu doprowadzenie do ograniczenia tej relacji (uwzględniając $\mathrm{w}$ szczególności propozycje rozwiązań prawnych mających na poziom wydatków i rozchodów w sektorze finansów publicznych), a także trzyletnią prognozę dotyczącą relacji wraz z przewidywanym rozwojem sytuacji makroekonomicznej kraju. Przyjęcie takiego programu nie oznacza jednak wprowadzenie proponowanych zmian w prawie w życie. Przepis art. 92 ust. 1 lit. b używa sformułowania „Rada Ministrów (...) przedstawia sejmowi program sanacyjny" co stanowi tylko obowiązek przedłożenia treści dokumentu pod obrady. Rząd musi jeszcze posiadać większość parlamentarną, która zagwarantuje mu uchwalenie wszystkich wymaganych przez program zmian prawnych. W wypadku więc rządu mniejszościowego plan może nie wejść w życie.

Projekt ustawy budżetowej nie może być przyjęty $\mathrm{z}$ ominięciem powyższych zakazów. Rada Ministrów musi zawsze przedstawić Sejmowi projekt ustawy budżetowej uwzględniający te relacje [por. Kosikowski 2006: 177]. Jest to szczególnie silny bodziec wobec rządu, który nie może zlekceważyć rosnącej relacji długu publicznego do PKB. Prawne uregulowanie ograniczeń budżetu państwa po przekroczeniu omówionych progów jest z założenia trafnym rozwiązaniem, które powinno zapewnić, że polski dług publiczny nie wymknie się spod kontroli. Niestety zarazem ustawa pozbawia elastyczności przy wyborze sposobu obniżenia długu publicznego. Przy przekroczeniu relacji długu do PKB 55\% z góry nakłada prawny obowiązek, aby budżet w następnym roku zamknął się bez deficytu, albo z takim saldem wydatków i dochodów, które tę relację zmniejszy. Oznacza to ciężkie skutki społeczne - wynikające z zamrożenia płac w sferze budżetowej, zmniejszeniu waloryzacji rent i emerytur, drastycznym zmniejszeniu wydatków, a co za tym idzie nakładów na opiekę społeczną, a także inwestycje. A przecież można sobie wyobrazić długofalowy plan redukcji wielkości długu publicznego, w którym przytoczonych skutków można uniknąć. Mimo to, z przepisów przyjętych przez ustawodawcę wynika brak wiary w takie rozwiązania i realistyczne podejście do sztuki uprawiania polityki finansowej w polskim państwie - zorientowanej najczęściej na bardzo krótkofalowe korzyści. 
Należy przy tym wskazać potencjalne problemy praktyczne, które mogą wyniknąć przy realizacji dyspozycji art. 86 ust. 1 pkt 2, nakazującej podjęcie określonych działań w celu obniżenia relacji długu do PKB, opisanych wcześniej jako sankcje za przekroczenie ,,progu 55\% PKB”. Ogół wątpliwości które się pojawiają uzasadnia moim zdaniem konieczność zastanowienia się nad gruntowną zmianą opisanej regulacji. Przede wszystkim ustawa nakazuje uchwalenie na następny rok ustawy budżetowej w której nie przewiduje się deficytu - albo przewiduje się taki poziom deficytu, przy którym relacja długu do PKB się zmniejszy. Trudno sobie wyobrazić, że w tak krótkim czasie Rada Ministrów jest w stanie podjąć działania, które spowodują ograniczenie wydatków lub wzrost dochodów publicznych o kwotę rzędu 40-50 mld złotych [Mączyński 2011: 179]. Już na wstępie poddaję w wątpliwość realność wypełnienia tej dyspozycji ustawodawcy. W pierwszym rzędzie realizację tego zapisu ma zapewnić „zamrożenie płac" w sferze budżetowej oraz waloryzacja rent i emerytur na poziomie nieprzekraczającym inflację. Obydwa działania wydają się być możliwe (zamrożenie płac pracowników sfery budżetowej stosowano już wielokrotnie). Dalej przewidziane są pewne ograniczenia zaciągania nowych zobowiązań na realizację inwestycji, oraz obniżenie dotacji udzielanej PFRON. Również w tym nie widzę wątpliwości. Niestety, podjęcie takich działań ledwie przybliży rząd do wypełnienia zadania przedstawienia ustawy budżetowej spełniającej powyższe wymagania. Bezsprzecznie dwa najważniejsze obowiązki dotyczą konieczności zmniejszenia wydatków finansowych z budżetu państwa, oraz poprawienie strony dochodowej budżetu poprzez np. dalsze podwyżki stawki podatku VAT (na co wprost wskazuje ustawodawca).

Zasadniczym problemem związanym ze zmniejszeniem przez rząd wydatków jest w głównej mierze ponad 70-procentowy udział w nich tzw. wydatków sztywnych. Możliwość zmiany stopnia ich wysokości jest skorelowana z obowiązkiem dokonania zmian legislacyjnych głównie na płaszczyźnie ustawodawczej. Powoduje to sytuację, w której samodzielność finansowa władzy publicznej jest znacznym stopniu ograniczona wolą polityczną osób będących członkami polskiego parlamentu [Ekonomiuk 2011: 204]. Przeprowadzenie zmian ustaw zmierzające do zmniejszenia wydatków może być bardzo utrudnione, albo nawet wręcz niemożliwe w krótkim czasie jednego roku budżetowego. Może także powstać sytuacja, w której rządząca koalicja rozpada się w obliczu niepopularnych zmian w wydatkowaniu publicznym i następuje konieczność przeprowadzenia przyspieszonych wyborów parlamentarnych. Pomijając sam fakt trudności w uzyskaniu szerokiego konsensusu członków parlamentu dla zmian ustawodawstwa powszechnego kreującego szeroki katalog tzw. wydatków sztywnych, zauważyć należy, iż znacznie większymi barierami dla racjonalizacji wydatkowej jest dylemat pomiędzy realizacją zasady równowagi budżetowej a jednocześnie zasadą demokratycznego państwa prawnego urzeczywistniającego zasady sprawiedliwości społecznej, jakim jest Rzeczpospolita Polska, co wprost wynika 
z art. 2 Konstytucji RP [Ekonomiuk 2011: 205]. W rezultacie przegląd wydatków sztywnych w krótkim czasie może zakończyć się tylko niewielkimi zmianami wydatków.

Mająca służyć pierwotnie jako uzupełniająca do sankcji dotyczących strony wydatkowej budżetu państwa czynność podniesienia stawek VAT (sfera dochodowa) okazać się może w praktyce dominującym i głównym instrumentem mającym na celu poprawę kondycji finansów publicznych poprzez zapewnienie zwiększonego strumienia dochodów, jakie z tytułu podatku od towarów i usług uzyskuje budżet państwa [Ekonomiuk 2011: 202]. Takie zjawisko już ma miejsce (podniesienie przez rząd premiera Donalda Tuska stawki od podatku VAT do 23\%) ale jest niewystarczające w hipotetycznej sytuacji przekroczenia relacji długu do PKB ponad 55\%. Co więcej sądzę, że rząd stający przed takim problemem nie zdecyduje się na kolejne podwyższenie stawki tego podatku, mając na uwadze możliwość głębokiego spadku poparcia społecznego. W rezultacie niemożności polepszenia wyniku strony dochodowej budżetu, prawdopodobnie zmniejszane byłyby wydatki rozwojowe np. na inwestycje.

Podsumowując, przepisy dotyczące progów ostrożnościowych z założenia wydają się odpowiednią metodą trzymania w ryzach wysokości długu publicznego, ale w przypadku praktycznego ich użycia może pojawić się szereg problemów, które obnażą słabość ustawowej regulacji - i z tego powodu powinny być zmienione. Może po prostu się okazać, że przepisy nie dadzą się wdrożyć w życie. Co więcej, wnioskując z zawieszenia przez rząd pierwszego progu ostrożnościowego nie należy wykluczyć, że dojdzie do zmian związanych z drugim progiem ostrożnościowym w niedalekiej przyszłości.

\section{STABILIZUJACA REGUŁA WYDATKOWA}

W polskim systemie prawnym od dawna próbowano wprowadzić reguły fiskalne, które mogłyby ostatecznie doprowadzić do równowagi finansów publicznych. Na uwagę zasługuje więc fakt, że w czasie trwania prac nad zawieszeniem pierwszej procedury ostrożnościowej przyjęto $\mathrm{w}$ dniu 6 czerwca $2013 \mathrm{r}$. projekt założeń do projektu ustawy o zmianie ustawy o finansach publicznych. Dokument ten zawiera ustalenia dotyczące wprowadzenia w Polsce nowej reguły fiskalnej, nazwanej ,stabilizującą regułą wydatkową”. Jak przyznano w dokumencie, „Obowiązujący dotychczas system reguł okazał się niewystarczający do zapewnienia dyscypliny fiskalnej. Nierównowaga finansów publicznych ma w Polsce charakter trwały" [Projekt zatożeń...: 2]. Nowa, wydajniejsza zasada wydatkowa ma wyróżniać się między innymi szerszym zakresem podmiotowym. Zgodnie z założeniami, reguła ma być wprowadzona poprzez nowelizację usta- 
wy o finansach publicznych w 2013 r. i będzie wyznaczana już przy wyznaczaniu limitu wydatków na rok 2014.

Reguła ma nakładać ograniczenia na poziom wydatków publicznych. W sytuacji zrównoważonych finansów publicznych limit wydatków będzie rósł w średniookresowym tempie wzrostu PKB. Punktem wyjścia dla wyznaczania limitu na rok $t+1$ będzie limit z roku $t$. Tak wyznaczona baza będzie następnie powiększana o średnie tempo wzrostu gospodarczego w czasie cyklu koniunkturalnego oraz o prognozowany wskaźnik inflacji na rok $t+1$. Zastosowanie takiego rozwiązania zapewni antycykliczny charakter stabilizującej reguły wydatkowej. W okresie dekoniunktury limit wydatków będzie bowiem rósł w szybszym tempie niż PKB, zaś w okresie dobrej koniunktury - w niższym tempie. Tak określone tempo byłoby ewentualnie korygowane $\mathrm{w}$ sytuacji niezrównoważenia finansów publicznych [Projekt założeń...: 6]. Powyższe założenie nowej reguły należy uznać za rozsądne. Dotychczas, w wyniku braku ograniczeń, w okresie prosperity gospodarczej do roku 2008 polskie wydatki publiczny stale rosły, nie przygotowano nadwyżek budżetowych, poprzez co finanse publiczne nie były przygotowane na przyjście kryzysu gospodarczego. Stąd uważam antycykliczny charakter nowej reguły wydatkowej za dobre rozwiązanie.

W założeniach do nowelizacji finansów publicznych proponuje się dodatkowo dwa warianty reguły korygującej finanse publiczne w razie ich niezrównoważenia. Niezależnie od zastosowanego wariantu, korekta będzie miała miejsce, gdy deficyt nominalny sektor instytucji rządowych i samorządowych (rozumiany jako deficyt sektora general government, określony zgodnie z rozporządzeniem Rady (WE) nr 2223/96 z dnia 15 czerwca 1996 r. w sprawie europejskiego systemu rachunków narodowych i regionalnych we wspólnocie) przekroczy 3\% PKB lub gdy państwowy dług publiczny przekroczy próg 55\% PKB. Jeśli państwowy dług publiczny znajdzie się w przedziale 50-55\% PKB, również zadziała korekta, ale relatywnie słabsza. W pierwszym wariancie wskazuje się osiągnięcie tzw. średniookresowego celu budżetowego (ang. medium term objective, MTO) w odniesieniu do wyniku strukturalnego instytucji rządowych i samorządowych. Poziom MTO jest określany w metodologii unijnej dla każdego kraju w ten sposób, aby zminimalizować ryzyko przekroczenia przez nominalny wynik sektora instytucji rządowych i samorządowych progu 3\% PKB. Celem operacyjnym reguły jest stabilizacja nominalnego wyniku sektora general government $\mathrm{w}$ relacji do PKB na poziomie równym MTO w średnim okresie. $\mathrm{W}$ drugim wariancie mechanizmu korygującego, celem operacyjnym jest stabilizacja państwowego długu publicznego na poziomie poniżej 40\% PKB. Korekta miałaby miejsce ciągle, dopóki dług publiczny nie obniżyłby się do tego poziomu. Następnie, wydatki rosłyby zgodnie ze średniookresowym tempem wzrostu PKB [Projekt założeń...: 7].

Nieprzestrzeganie reguły będzie wiązało się z tymi samymi konsekwencjami, co złamanie ustawy o finansach publicznych. Przewidziano jednak tzw. 
klauzulę wyjścia, czyli okoliczności, w których możliwe będzie zawieszenie określania limitu wydatków publicznych według formuły wynikającej z proponowanej reguły. Okoliczności te będą stanowiły wyłącznie skrajne sytuacje: stan wojenny, stan wyjątkowy albo klęski żywiołowej na całym terytorium Rzeczypospolitej Polskiej.

Ostatecznie ocena nowej reguły wydatkowej będzie możliwa dopiero po jej wdrożeniu w życie. Trudno na tym etapie przewidzieć, czy przyniesie ona realny postęp na drodze do uzdrowienia finansów publicznych. Będzie to zależało zarówno od strony prawnej całego przedsięwzięcia, jak i faktycznego jej egzekwowania.

\section{PODSUMOWANIE}

Przepisy regulujące kwestię długu publicznego powinny stanowić pole do istotnych, przemyślanych zmian w przyszłości, ze szczególnym zwróceniem uwagi na zasygnalizowane wyżej problemy. Począwszy od faktu, że wysokość długu publicznego liczona metodą polską jest zaniżona w stosunku do metody ESA 95 stosowanej w Unii Europejskiej, poprzez wgląd na hipotetyczną niemożliwość zastosowania reguł 55\% progu ostrożnościowego, a skończywszy na niezgodności art. 72 ust. 1 z Konstytucją. Niezależnie od powyższego, w niedalekiej przyszłości warto będzie przypatrywać się działaniu w praktyce nowej reguły wydatkowej, co pozwoli ocenić czy nowo proponowana regulacja spełniła swoje zadanie - ograniczenia wzrostu wydatków publicznych.

\section{BIBLIOGRAFIA}

Bitner M., Kulesza M., 2011, Nowa definicja państwowego dtugu publicznego? Problemy zwiąane z interpretacja przepisów rozporządzenia Ministra Finansów z 23.12.2010 r. w sprawie szczegótowego sposobu klasyfikacji tytułów dtużnych zaliczanych do państwowego dtugu publicznego, w tym do dtugu Skarbu Państwa, „Samorząd Terytorialny”, nr 7-8.

E k o n o mi u k J., 2011, Problemy realizacji prawnych konsekwencji przekroczenia 55-procentowego wskaźnika polskiego dtugu publicznego, [w:] A. Po mors k a (red.), Ekonomiczne i prawne uwarunkowania redukcji deficytu i dtugu publicznego, Wolters Kluwer, Warszawa.

Karlik ow sk a M., 2010, Ustawa o finansach publicznych - komentarz, Presscom, Wrocław.

Kosi kows ki C., 2006, Finanse publiczne - komentarz, Wydawnictwo Prawnicze LexisNexis, Warszawa.

Mąc z y ńs ki D., 2011, Procedury ostrożnościowe i sanacyjne - instrument ochrony przed nadmiernym zadtużeniem?, [w:] A. P o mors k a (red.), Ekonomiczne i prawne uwarunkowania redukcji deficytu i dtugu publicznego, Wolters Kluwer, Warszawa.

Projekt zatożeń do projektu ustawy o zmianie ustawy o finansach publicznych z 6 czerwca 2013 r., nr PF5/0310/5/31/DMK/13/RD-55507. 
Ruśk ow ski E., S al a chn a J. (red.), 2010, Nowa ustawa o finansach publicznych wraz z ustawa wprowadzająca. Komentarz praktyczny, Gdańsk.

Ustawa z dnia 26 lipca 2013r. o zmianie ustawy o finansach publicznych, DzU 2013, nr 0, poz. 938.

Ziółkowska W., 2012, Finanse publiczne - teoria $i$ zastosowanie, Wydawnictwo Wyższej

Szkoły Bankowej, Poznań.

\section{PUBLIC DEBT AND PRACTICAL PROBLEMS REGARDING THE USE OF THE PRUDENCE AND RECOVERY PROCEDURES}

The goal of the article is to present actual problems regarding the definition of public debt in the polish financial law, its compliance with polish constitution and doubts surrounding the eventual usage of safety and prudence procedures in the context of public debt. The author expresses his concern about current regulations and believes that a quick legislator's intervention is needed. Finally the article aims to analyze the newly introduced procedure about stabilizing national expenditure.

Key words: public finances, public debt, budget deficit, prudence procedures. 